\title{
WHOLE BRAIN TEACHING SEBAGAI DESAIN PEBELAJARAN MATEMATIKA YANG KREATIF
}

\author{
Elita Mega Selvia Wijaya ${ }^{1}$, Nathasa Pramudita Irianti $^{2}$ \\ 1,2 Fakultas Ilmu Pendidikan, Universitas Tribhuwana Tunggadewi \\ elita.selvia@gmail.com ${ }^{1}$, nathasa1990@gmail.com²
}

\begin{abstract}
ABSTRAK
Penelitian bertujuan untuk memperoleh desain pembelajaran berbasis karakter kreatif melalui pendekatan Whole Brain Teaching pada materi grafik garis lurus yang valid, praktis dan efektif. Pengembangan desain pembelajaran ini didasarkan pada model pengembangan Plomp, yang terdiri dari empat fase, yaitu: (1) investigasi awal, (2) desain atau perancangan, (3) realisasi atau konstruksi, dan (4) tes, evaluasi, revisi. Fase investigasi awal meliputi investigasi pengetahuan prasyarat, mengamati dan analisis perilaku siswa, mengkaji kurikulum dan silabus, serta investigasi sumber pendukung. Fase perancangan diantaranya merancang pengorganisasian materi menjadi unit-unit yang utuh, berdasarkan karakteristik materi dan alokasi waktu, membuat pemetaan materi dan aktivitas PBM yang relevan, serta membuat rancangan RPP dan LKS. Dalam fase realisasi, dikembangkan dua perangkat yaitu RPP dan LKS. Di fase terakhir, yaitu tes evaluasi, dilakukan validasi dan uji coba lapangan. Berdasarkan hasil analisis data, desain pembelajaran matematika berdasarkan Whole Brain Teaching dapat diterapkan dan terlaksana dengan baik. Hal ini ditunjukkan dari tingkat keterlaksanaan lebih dari $75 \%$ dan masing-masing aktivitas terlaksana di atas $61 \%$. Hasil ini diperkuat dengan hasil wawancara yang berpendapat bahwa pembelajaran persamaan garis lurus menggunakan Whole Brain Teaching cukup baik dan menyenangkan, secara umum menyampaikan gesture yang dipakai pada pembelajaran dapat membantu dalam memahami konsep persamaan dan grafik garis lurus dan meningkatkan daya ingat.
\end{abstract}

Kata Kunci: Desain Pembelajaran, Matematika Kreatif, Whole Brain Teaching.

\begin{abstract}
The study aims to create a creative character-based learning design through Whole Brain Teaching approach. The development of this design is based on the development model proposed by Plomp, which consists of four phases, there are: (1) initial investigation, (2) design, (3) realization or construction, and (4) test, evaluation, revision. The initial investigative phase includes investigation of basic knowledge, observing and analyzing student behavior, assessing curriculum and syllabus, as well as investigating supportive sources. The design phase involves designing the material into full units, based on material characteristics and time allocation, making mapping of relevant materials and activities, and arrange RPP and students worksheet. In the realization phase, two sets of RPP and students worksheet were developed. In the last phase, the evaluation test, validation and field trials. Based on the results of data analysis, the design of mathematics learning based on Whole Brain Teaching can be applied and implemented. This is shown from the implementation rate of more than $75 \%$ and each activity is performed above $61 \%$. These results are reinforced by interviews that show by using Whole Brain Teaching is good and fun, the gestures used in learning can help in understanding the concepts of this material.
\end{abstract}

Key Words: Learning Design, Creative Mathematics, Whole Brain Teaching.

\section{PENDAHULUAN}

Berdasarkan Undang-undang Nomor 20 Tahun 2003 tentang Sistem

Pendidikan Nasional (UU Sisdiknas), Pemerintah berkewajiban memenuhi hak 
setiap warga negara untuk memperoleh pendidikan yang bermutu. Salah satu faktor penentu keberhasilan sistem pembelajaran menurut Sanjaya (2006:52) yaitu guru, siswa, sarana, alat media yang tersedia dan lingkungan belajar. Semua faktor tersebut saling mendukung, berpengaruh dan tidak dapat dipisahkan. Guru dan siswa memegang peranan penting dalam pembelajaran. Guru harus mempunyai penguasaan materi ajar yang baik dan dapat merencanakan pembelajaran yang berorientasi untuk membelajarkan siswa. Penggunaan metode dan teknik mengevaluasi hasil pembelajaran siswa merupakan faktor yang sangat penting juga. Selain itu, sesuai dengan kurikulum 2013 yang mengembangkan beberapa karakter pada peserta didik, guru juga dituntut untuk dapat memahami karakter masing-masing peserta didiknya. Pada penelitian ini dipilih salah satu karakter yaitu karakter kreatif berdasarkan UU No. 20 Tahun 2003, sehingga tujuan satuan pendidikan dapat terwujud.

Berpikir kreatif menurut Munandar (dalam Moma,2012:507) merupakan berbagai cara untuk memperoleh jawaban berdasarkan informasi yang diberikan pada keragaman jumlah dan kesesuaian,. Terdapat empat karakteristik berpikir kreatif menurut Gilferd dan Torrance (2012), yaitu (a) orisinalitas atau menyusun sesuatu yang baru (originality); (b) kelancaran atau menurunkan banyak ide (fluency); (c) fleksibilitas atau mengubah perspektif dengan mudah (flexibility); dan (d) elaborasi atau mengembangkan ide lain dari suatu ide (elaboration). Penelitian tentang karakter kreatif telah dilakukan oleh Komariah (2012:455) yang menunjukkan bahwa rata-rata aspek keterampilan berpikir kreatif siswa semakin meningkat. Oleh karena itu, desain pembelajaran matematika berbasis karakter kreatif diharapkan dapat membantu guru untuk memunculkan dan mengembangkan karakter kreatif siswa, sehingga desain ini perlu dikembangkan

Berdasarkan hasil investigasi awal, materi grafik garis lurus di SMP Negeri 1 Singosari disampaikan guru dengan cara menuliskan rumus-rumus dan memberikan contoh soal. Dari fakta tersebut terlihat bahwa metode yang digunakan oleh guru masih kurang variatif. Siswa menjadi cepat bosan dan lupa sehingga menganggap materi grafik garis lurus adalah materi yang sulit. Hal ini akan berdampak pada pencapaian hasil belajar yang tidak maksimal. 
Kondisi tersebut merupakan masalah serius dalam pembelajaran matematika. Guru harus mampu menyusun desain pembelajaran dengan pemilihan metode yang sesuai dengan materi yang disampaikan agar dapat melayani berbagai karakteristik siswa. Dengan demikian diperlukan alternatif desain pembelajaran yang dapat mengantarkan siswa pada pencapaian hasil belajar yang optimal. Whole Brain Teachingsebagai salah satu metode yang dapat diterapkan dalam menyusun desain pembelajaran untuk antisipasi masalah pembelajaran matematika. Menurut Bawaneh (2011) metode Whole Brain Teaching lebih berhasil dibandingkan dengan pembelajaran konvensional. Desain pembelajaran yang disusun berdasarkan Whole Brain Teaching memungkinkan guru dan siswa untuk mengintegrasikan sistem manajemen kelas yang efektif dengan pendekatan belajar yang memanfaatkan otak secara keseluruhan. Desain ini dapat meningkatkan sistem penyimpanan informasi siswa terhadap konsep-konsep dasar materi pembelajaran sampai dengan keterampilan berpikir tingkat tinggi (Sumarticus, 2011), selain itu berdasarkan penelitian Torio (2016) dan Akyurek (2013) menunjukkan bahwa dengan menggunakan strategi mengajar dengan whole Brain Teaching menunjukkan efek positif untuk akademik kinerja dan motivasi. Desain pembelajaran berdasarkan Whole Brain Teaching dipilih peneliti karena dapat meningkatkan peran aktif siswa dalam kegiatan pembelajaran, meningkatkan motivasi dan kemampuan siswa untuk mengkomunikasikan matematika (Chris Biffle, 2010).

\section{METODE PENELITIAN}

Pengembangan desain pembelajaran matematika berbasis kreatif siswa melalui pendekatan Whole Brain Teaching didasarkan pada model pengembangan yang dikemukakan oleh Plomp. Untuk mendukung pelaksanaan desain ini, pada situasi masalah, maka dikembangkan perangkat pembelajaran dan instrumen. Karena itu penelitian ini dikategorikan sebagai penelitian pengembangan (developmental research). Penelitian pengembangan pada hakekatnya adalah meningkatkan kualitas, produk yang berupa prototipe dan membangun langkahlangkah metodologis untuk perancangan dan penilaian produk itu. Sedangkan jika dilihat lebih lanjut, pengembangan bersifat cyclic dan meliputi aktivitas analisis, desain, evaluasi, dan revisi. Siklus ini berulang hingga diperoleh produk yang 
memiliki kriteria tertentu. Kegunaan dari tiap-tiap produk yang akan dikembangkan disajikan pada tabel 1 berikut.

Tabel 1. Produk dan Kegunaannya

\begin{tabular}{lll}
\hline \multicolumn{1}{c}{ Produk } & \multicolumn{1}{c}{ Kegunaan } & \multicolumn{1}{c}{ Keterangan } \\
\hline Desain & Melaksanakan desain & Untuk uji coba di \\
Pembelajaran & pembelajaran di lapangan & lapangan \\
& Mengukur kepraktisan dan & \\
& keefektifan desain & \\
\hline Instrumen & Menilai kualitas Perangkat, & Melalui validasi \\
& meliputi: & ahli \\
& $\bullet$ Kevalidan, & Melalui uji coba \\
& $\bullet$ Kepraktisan, & lapangan \\
& $\bullet$ Keefektifan & \\
\hline
\end{tabular}

Berdasarkan langkah-langkah Plomp, maka pengembangan perangkat pembelajaran dilakukan dalam empat tahap penelitian atau empat fase, yaitu: (1) investigasi awal. Fase Investigasi Awal meliputi: investigasi pengetahuan prasyarat; mengamati dan analisis perilaku siswa dalam kegiatan belajar mengajar; mengkaji kurikulum dan silabus; dan investigasi sumber-sumber pendukung; (2) desain atau perancangan. Pada fase perancangan, dilakukan perancangan pengorganisasian materi menjadi unit-unit yang utuh berdasarkan karakteristik materi dan alokasi waktu, pemetaan materi dan aktivitas PBM yang relevan, serta pembuatan rancangan Rencana Pelaksanaan Pembelajaran (RPP) dan Lembar kegiatan siswa (LKS); (3) realisasi atau konstruksi. Realisasi/Kontruksi/Produksi, ada dua perangkat yang dikembangkan, yaitu: Rencana Pelaksanaan Pembelajaran (RPP), dan Lembar kegiatan siswa (LKS). Rencana Pelaksanaan Pembelajaran ini merupakan panduan bagi guru untuk melaksanakan tahap-tahap pembelajaran. Sedangkan lembar kegiatan siswa berfungsi untuk mengungkap seluruh aktivitas siswa dalam pembelajaran. Dalam merealisasikan RPP dilakukan aktivitas antara lain: (a) menetapkan kompetensi dasar dan indikator, (b) menentukan materi prasyarat, (c) menentukan alat-alat yang diperlukan, dan (d) menyusun skenario pembelajaran. Sedangkan aktivitas dalam merealisasikan lembar kegiatan siswa adalah: (a) menyusun cara penyajian informasi, (b) menyusun aktivitas Whole Brain dan (c) menyusun aktivitas pemantapan. dan (4) tes, evaluasi, revisi. Untuk tahap Di fase terakhir, yaitu fase Tes, Evaluasi, dan Revisi dilakukan dua kegiatan 
utama yaitu: (a) kegiatan validasi. Aktivitas yang tercakup dalam proses validasi ini antara lain: Meminta penilaian ahli dan praktisi tentang kelayakan desain pembelajaran yang telah dibuat. Penilaian ini menggunakan lembar validasi rencana pelaksanaan pembelajaran (RPP) dan lembar validasi lembar kegiatan siswa (LKS) yang diberikan ke validator; Melakukan analisis terhadap penilaian validator. Jika hasil analisis menunjukkan: Valid tanpa revisi maka kegiatan selanjutnya adalah uji coba di lapangan; Valid dengan sedikit revisi maka kegiatan selanjutnya adalah melakukan revisi terlebih dahulu, kemudian langsung uji coba lapangan; dan Tidak valid, maka dilakukan revisi sehingga dihasilkan prototipe baru kemudian meminta kembali penilaian kelayakan (validasi) para ahli dan praktisi (kembali ke langkah meminta penilaian ahli dan praktisi ulang. dan (b) kegiatan uji coba pada situasi nyata di lapangan.

Kegiatan yang dilaksanakan pada tahap uji coba ini adalah melaksanakan pembelajaran sebagaimana telah direncanakan dalam RPP. Untuk melihat kepraktisan dan keefektifan perangkat pembelajaran diperlukan observer. Observer pada penelitian ini adalah guru matematika SMP Negeri 1 Singosari yang sudah tersertifikasi sebanyak 3 orang. Observasi dilaksanakan selama pembelajaran berlangsung sebanyak waktu penelitian yang telah direncanakan. Subjek penelitian ini adalah siswa kelas VIII B SMP Negeri 1 Singosari tahun pelajaran 2016/2017. Jumlah siswa sebanyak 30 orang dan digunakan untuk melaksanakan uji coba.

Jenis data pada penelitian ini ada dua yaitu data kualitatif dan data kuantitatif. Data kualitatif berupa tanggapan dan saran perbaikan dari validator, praktisi maupun siswa. Sedangkan data kuantitatif diperoleh dari skor hasil validasi, skor pada lembar observasi dan skor hasil tes penguasaan bahan ajar (TPBA) materi Persamaan dan Grafik Garis Lurus. Instrumen yang dikembangkan dalam penelitian bertujuan untuk mengumpulkan data yang diperlukan untuk menilai desain beserta perangkat-perangkatnya. Untuk itu dikembangkan instrumen yang meliputi: (1) lembar validasi perangkat pembelajaran dan instrumen penelitian, (2) lembar observasi aktivitas guru, (3) lembar observasi aktivitas siswa, (4) lembar wawancara siswa, dan (5) tes penguasaan bahan ajar (TPBA). Teknik Analisis pada penelitian ini adalah analisis data kevalidan desain, analisis data kepraktisan desain, dan analisis data keefektifan desain. 
Metode penelitian dengan komposisi $8-10 \%$ dari total halaman artikel.

\section{HASIL PENELITIAN DAN PEMBAHASAN}

Desain pembelajaran yang mencakup Rencana Pelaksanaan Pembelajaran (RPP) dan Lembar Kegiatan Siswa (LKS) dalam penelitian ini dikembangkan berdasarkan model umum pemecahan masalah, Plomp, yaitu: (1) Investigasi Awal,

(2) Desain atau Perencanaan, (3) Realisasi atau Konstruksi dan (4) Tes/Evaluasi/Revisi.

\section{a. Hasil Investigasi Awal}

Investigasi awal dalam pengembangan desain ini mencakup empat hal yaitu: (1) investigasi pengetahuan prasyarat. Materi yang akan dibahas pada penelitian ini adalah persamaan dan grafik garis lurus. Penyajian materi persamaan dan grafik garis dimulai dari konsep tentang persamaan dan cara menggambar grafik fungsi linear. Dengan demikian, pengetahuan prasyarat yang diperlukan siswa untuk menguasai materi persamaan dan grafik garis lurus adalah pengertian persamaan dan menggambar grafik fungsi linear yang telah dipelajari di kelas tujuh. Sehingga dalam mempelajari persamaan dan grafik fungsi, maka siswa harus memahami pengetahuan prasyarat; (2) mengamati dan analisis kegiatan belajar mengajar siswa. Berdasarkan hasil observasi peneliti, kegiatan belajar mengajar di SMP Negeri 1 Singosari khususnya kelas VIII sudah berjalan dengan baik. Guru sudah menggunakan beberapa pendekatan dan model pembelajaran, tetapi masih dijumpai sebagian siswa yang kurang aktif dalam setiap tahap pembelajaran sehingga kurang maksimal dalam menggali kemampuannya. Selain itu, masih terdapat pula beberapa siswa yang selalu ramai di kelas, tidak bisa fokus pada materi pelajaran dan kurang memperhatikan penjelasan guru. Guru sudah menggunakan berbagai metode pembelajaran untuk meningkatkan karakter kreatif siswa, tetapi belum pernah menggunakan pendekatan atau model pembelajaran yang bersamaan melibatkan kemampuan siswa baik secara verbal, visual maupun kinestetik. Situasi ini dapat dikembangkan dengan Pembelajaran berdasarkan Whole Brain Teaching untuk lebih mengembangkan karakter kreatif dan prestasi belajar siswa; 3) mengkaji kompetensi inti dan kompetensi dasar dan (4) investigasi sumber-sumber 
Whole Brain Teaching Sebagai Desain Pebelajaran Matematika Yang Kreatif

pendukung. Sumber pendukung pembelajaran persamaan dan grafik garis lurus ini adalah buku teks siswa, yaitu buku siswa matematika kurikulum 2013.

\section{b. Hasil Fase Desain}

Hasil dari fase desain pembelajaran pada penelitian ini adalah rancangan Rencana Pelaksanaan Pembelajaran (RPP) dan Lembar Kegiatan Siswa (LKS). Rancangan RPP dan LKS ini memuat dua komponen pokok, yaitu informasi umum dan langkah-langkah pembelajaran. Informasi umum pada rancangan RPP meliputi: (1) identitas mata pelajaran; (2) kompetensi inti; (3) kompetensi dasar; (4) indikator pencapaian kompetensi; (5) tujuan pembelajaran; (6) materi pembelajaran; (7) model/metode pembelajaran; (8) media/alat; (9) sumber dan evaluasi. Sedangkan pada rancangan LKS informasi umum terdiri dari: (1) identitas mata pelajaran, (2) tujuan pembelajaran, (3) petunjuk penggunaan LKS dan (4) aturan dalam Whole Brain Teaching.

Rancangan langkah-langkah pembelajaran dalam LKS berisi rancangan penyajian informasi dan proses pengambilan kesimpulan tentang sejumlah ide dan keterkaitannya dalam menyelesaikan masalah matematika yang diukur melalui kemampuan siswa memberi penegasan hasil diskusi dengan memberikan penjelasan menggunakan gesture kemudian menarik kesimpulan. Rancangan langkah-langkah pembelajaran dalam RPP memuat aktivitas guru dan siswa dalam tiap-tiap langkah pembelajaran.

\section{c. Hasil Fase Realisasi}

Rancangan-rancangan yang telah disusun dalam fase desain selanjutnya direalisasikan sehingga diperoleh prototipe 1 dari RPP dan LKS sesuai dengan desain yang telah disusun dan dapat dilihat pada lampiran.

\section{d. Hasil Tes/Evaluasi/Revisi}

Hasil fase ini dapat dibedakan menjadi dua, yaitu hasil validasi dan hasil uji coba di lapangan. Hasil validasi digunakan untuk menilai validitas perangkat sebelum pelaksanaan uji coba di lapangan, sedangkan hasil uji coba lapangan digunakan untuk menilai kepraktisan dan keefektifan perangkat pembelajaran. 
Hasil validasi dibuat keputusan, apakah perangkat masih perlu revisi sebelum uji coba atau telah siap diujicobakan di lapangan. Pada Tabel 1 berikut merupakan rata-rata hasil validasi RPP, Lembar Kerja Siswa (LKS), lembar observasi aktivitas guru dan siswa, tes penguasaan bahan ajar (TPBA), dan pedoman wawancara.

Tabel 2. Rekapitulasi Hasil Validasi dari Semua Validator

\begin{tabular}{|c|c|c|}
\hline Indikator Kevalidan & Hasil Validasi & Kesimpulan \\
\hline $\begin{array}{l}\text { Rencana pelaksanaan } \\
\text { Pembelajaran (RPP) }\end{array}$ & $\begin{array}{l}\text { Rata-rata keseluruhan hasil } \\
\text { validasi adalah } 3,80\end{array}$ & $\begin{array}{l}\text { Memenuhi kriteria } \\
\text { kevalidan }\end{array}$ \\
\hline $\begin{array}{l}\text { Lembar Kerja Siswa } \\
(\mathrm{LKS})\end{array}$ & $\begin{array}{l}\text { Rata-rata keseluruhan hasil } \\
\text { validasi adalah } 3,70\end{array}$ & $\begin{array}{l}\text { Memenuhi kriteria } \\
\text { kevalidan }\end{array}$ \\
\hline $\begin{array}{l}\text { Lembar Observasi } \\
\text { Aktivitas Guru }\end{array}$ & $\begin{array}{l}\text { Rata-rata keseluruhan hasil } \\
\text { validasi adalah } 3,74\end{array}$ & $\begin{array}{l}\text { Memenuhi kriteria } \\
\text { kevalidan }\end{array}$ \\
\hline $\begin{array}{l}\text { Lembar Observasi } \\
\text { Aktivitas Siswa }\end{array}$ & $\begin{array}{l}\text { Rata-rata keseluruhan hasil } \\
\text { validasi adalah } 3,81\end{array}$ & $\begin{array}{l}\text { Memenuhi kriteria } \\
\text { kevalidan }\end{array}$ \\
\hline $\begin{array}{l}\text { Tes Penguasaan Bahan } \\
\text { Ajar (TPBA) }\end{array}$ & $\begin{array}{l}\text { Rata-rata keseluruhan hasil } \\
\text { validasi adalah } 3,82\end{array}$ & $\begin{array}{l}\text { Memenuhi kriteria } \\
\text { kevalidan }\end{array}$ \\
\hline Pedoman Wawancara & $\begin{array}{l}\text { Rata-rata keseluruhan hasil } \\
\text { validasi adalah } 3,81\end{array}$ & $\begin{array}{l}\text { Memenuhi kriteria } \\
\text { kevalidan }\end{array}$ \\
\hline
\end{tabular}

\section{Hasil Uji Coba dan Analisis Data}

Uji coba ini pada hakekatnya adalah untuk menilai kepraktisan dan keefektifan desain. Untuk melaksanakan desain itu, maka dikembangkan perangkat pembelajaran. Perangkat yang dikembangkan adalah RPP dan LKS. Pada setiap pertemuan siswa mengerjakan satu LKS dan dikumpulkan pada akhir pertemuan. Materi yang dipakai dalam uji coba ini adalah Grafik Garis Lurus. Uji coba perangkat ini dilakukan sekali, dalam arti dilakukan satu siklus yang terdiri dari lima kali tatap muka. Uji coba ini diobservasi oleh tiga pengamat (observer), dua orang mengamati aktivitas siswa dan satu orang mengamati aktivitas guru. Observer adalah dua dosen matematika dan satu guru matematika. Hasil uji coba selengkapnya diuraikan sebagai berikut.

\section{a. Kepraktisan Desain}

Desain pembelajaran dikatakan praktis jika ahli dan praktisi menyatakan desain itu dapat diterapkan dan pengamatan tentang keterlaksanaan pembelajaran memenuhi kategori minimal baik. Kategori baik diperoleh melalui skor pengamatan menggunakan lembar observasi aktivitas guru. Secara keseluruhan, rata-rata 
keterlaksanaan desain adalah 94.00\%, sehingga menurut kriteria yang telah ditentukan, keterlaksanaan desain masuk kategori sangat baik.

\section{b. Keefektifan Desain}

Desain pembelajaran dikatakan efektif jika penguasaan bahan ajar dan aktivitas siswa memenuhi kategori minimal baik. Hasil uji coba tentang keefektifan desain disajikan sebagai berikut.

(a) Penguasaan Bahan Ajar

Penguasaan bahan ajar mencakup dua aspek yaitu nilai tes penguasaan bahan ajar (TPBA) dan nilai WBT. Tes penguasaan bahan ajar dilaksanakan satu kali pada akhir kegiatan uji coba. Hal ini dimaksudkan agar memudahkan untuk melihat tingkat penguasaan bahan ajar dalam mengaplikasikan gesture tertentu yang sudah dimiliki siswa. Sedangkan nilai WBT diambil dari rata-rata seluruh nilai siswa pada aktivitas pengerjaan soal comprehension check yang terdapat di Lembar Kegiatan Siswa (LKS) pada setiap akhir kegiatan belajar mengajar. Nilai TPBA diberi bobot $70 \%$ dan nilai WBT diberi bobot 30\%. Berdasarkan analisis data didapatkan hasil banyaknya siswa yang telah memenuhi KBM adalah 93,33\%. Berdasarkan kriteria yang ditentukan, maka tingkat penguasaan bahan ajar siswa kelas VIII C tuntas secara klasikal dan memenuhi kategori sangat baik.

(b) Hasil Uji Coba LKS

Dalam penelitian ini siswa bekerja dalam bentuk kelompok. Sebelum melaksanakan kegiatan-kegiatan pada LKS, guru meminta siswa membaca kembali petunjuk yang ada agar siswa dapat melaksanakan kegiatan sesuai yang diharapkan. Siswa juga diberi kesempatan untuk menanyakan kembali jika terdapat perintahperintah yang tidak dimengerti. Pada kegiatan 1, LKS-1 masih terdapat kelompok siswa yang melakukan kesalahan. Siswa diminta menggambar garis-garis yang terdapat pada permukaan benda yang dipilih, tetapi mereka masih mengambar kurva yang menurut mereka adalah garis lengkung. Kegiatan ini dimaksudkan agar siswa mempunyai pengalaman untuk mengidentifikasi garis-garis yang terdapat pada permukaan benda-benda yang ada di kelas. Dengan memilih sendiri bendanya diharapkan siswa mampu menemukan beberapa macam garis berdasarkan kemiringannya. Meskipun guru sudah memberi keterangan secara lisan bahwa garis 
yang dimaksud adalah garis lurus, tetapi masih terdapat siswa yang tidak memahaminya. Contoh pekerjaan siswa ini disajikan pada Gambar 1.

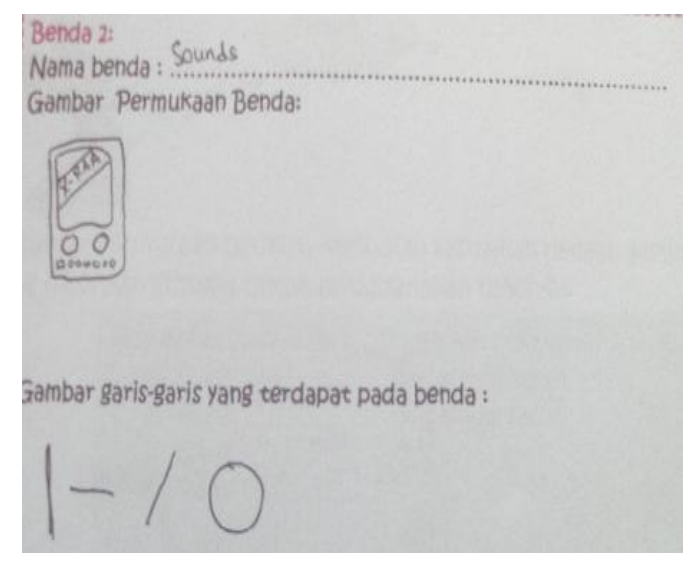

\section{Gambar 1. Contoh pekerjaan siswa}

Hasil kerja dari kelompok lain sudah sesuai dengan tujuan peneliti yaitu dapat menyimpulkan macam-macam garis berdasarkan arah kemiringannya. Gambar 2 merupakan salah satu contoh pekerjaan siswa yang sesuai harapan.

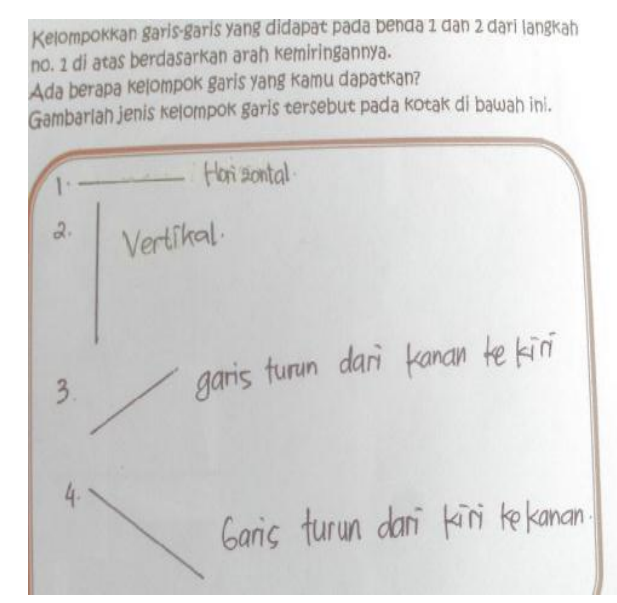

Gambar 2. Contoh pekerjaan siswa

Berdasarkan data dan hasil analisis, desain pembelajaran matematika berdasarkan Whole Brain Teaching dapat diterapkan dan terlaksana dengan baik. Hal ini ditunjukkan dari semua langkah mempunyai tingkat keterlaksanaan lebih dari $75 \%$ dan masing-masing aktivitas terlaksana di atas $61 \%$. Hasil di atas diperkuat hasil wawancara, dimana secara umum siswa yang diwawancarai menunjukkan hal yang sama. Siswa berpendapat bahwa pembelajaran persamaan garis lurus menggunakan Whole Brain Teaching cukup baik dan menyenangkan, 
secara umum menyampaikan gesture yang dipakai pada pembelajaran dapat membantu dalam memahami konsep persamaan dan grafik garis lurus dan membuat daya ingat mereka lebih tahan lama. Kegiatan class-yes membantu sekali dalam memusatkan perhatian dalam pembelajaran dan tidak ada kesulitan dalam melaksanakan kegiatan teach-ok dan switch-ok. Artinya hasil uji coba LKS yang diamati melalui aktivitas siswa mempunyai kesesuaian data hasil wawancara.

\section{c. Revisi Produk}

Berdasarkan analisis data hasil uji coba, secara umum tingkat ketercapaian pengembangan perangkat pembelajaran dan instrumen sudah menunjukkan hasil baik dan tidak perlu dilakukan revisi.

\section{SIMPULAN}

Berdasarkan data dan hasil analisis, desain pembelajaran matematika berdasarkan Whole Brain Teaching dapat diterapkan dan terlaksana dengan baik. Hal ini ditunjukkan dari semua langkah mempunyai tingkat keterlaksanaan lebih dari $75 \%$ dan masing-masing aktivitas terlaksana di atas $61 \%$. Hasil ini diperkuat dengan hasil wawancara, dimana secara umum siswa yang diwawancarai menunjukkan hal yang sama. Siswa berpendapat bahwa pembelajaran persamaan garis lurus menggunakan Whole Brain Teaching cukup baik dan menyenangkan, secara umum menyampaikan gesture yang dipakai pada pembelajaran dapat membantu dalam memahami konsep persamaan dan grafik garis lurus dan membuat daya ingat mereka lebih tahan lama.

\section{DAFTAR PUSTAKA}

Akyurek, E., \& Afacan, O. (2013). Effects of brain-based learning approach on students' motivation and attitudelevels in science class. Mevlana International Journal of Education, 3(1), 104-119. (Online) (http://dx.doi.org/10.13054/mije.13.08.3.1) diakses 1 Mei 2016.

Amstrong, Tricia.2009. The Whole Brain Solution. Jakarta: Grafindo.

Biffle, Chriss. 2010. Whole Brain Teaching, (Online). (http://www.wholebrainteaching.com) diakses 20 Oktober 2011

Komariah, Kokom. 2011. Efektivitas Metode Demonstrasi dalam Meningkatkan Keterampilan Berpikir Kreatif Siswa.Prosiding Seminar Nasional Matematika UNY. 
Moma, La. 2012. Menumbuhkan Kemampuan Berpikir Kreatif Matematis Melalui Pembelajaran Generatif Siswa. Prosiding Seminar Nasional Matematika $U N Y$.

Sanjaya, Wina. 2006.Strategi Pembelajaran Berorientasi Standar Proses Pendidikan. Jakarta: Kencana Prenada Media Group

Sofan, Amri dkk, 2010.Proses Pembelajaran Kreatif dan Inovatif dalam Kelas. Jakarta: Pustakaraya

Sumarticus, 2011.Whole Brain Teaching- Make Teaching Fun Again. (online).http://smarticus.hubpages.com/hub/What-is-Power-Teaching. (diakses 12 Mei 2016)

Torio, Von Anthony. 2016. Whole brain teaching in the Philippines: Teachingstrategyfor addressing motivation and academic performance. International Journal of Research Studies in Education2016 July, Volume 5 Number 3, 59-70, (Online)(http://www.consortiacademia.org/index.php/ ijrse/article/view/1289) diakses 2 Mei 2016. 